\title{
Modifications of expression of genes and proteins involved in DNA repair and nitric oxide metabolism by carbatonides [disodium-2,6-dimethyl-1,4-dihydropyridine- 3,5-bis(carbonyloxyacetate) derivatives] in intact and diabetic rats
}

\author{
Kristīne Ošinaa ${ }^{1,2}$, Elina Leonova ${ }^{2,3}$, Sergejs Isajevs ${ }^{2,3}$, Larisa Baumane ${ }^{2,3}$, Evita Rostoka ${ }^{2,3}$, \\ Tatjana Sjakste' ${ }^{1}$ Egils Bisenieks², Gunars Duburs², Brigita Vīgante², and Nikolajs Sjakste²,3
}

Genomics and Bioinformatics, Institute of Biology of the University of Latvia, Salaspils ${ }^{1}$, Latvian Institute of Organic Synthesis ${ }^{2}$, Faculty of Medicine, University of Latvia ${ }^{3}$, Riga, Latvia

[Received in January 2017; Similarity Check in February 2017; Accepted in August 2017]

\begin{abstract}
Studies on the pathogenesis of diabetes mellitus complications indicate that the compounds reducing free radicals and enhancing DNA repair could be prospective as possible remedies. Carbatonides, the disodium-2,6-dimethyl-1,4dihydropyridine-3,5-bis(carbonyloxyacetate) derivatives, were tested for these properties. EPR spectroscopy showed that metcarbatone was an effective scavenger of hydroxyl radicals produced in the Fenton reaction, etcarbatone, and propcarbatone were less effective, styrylcarbatone was ineffective. UV/VIS spectroscopy revealed that styrylcarbatone manifested a hyperchromic effect when interacting with DNA, while all other carbatonides showeda hypochromic effect. Rats with streptozotocin induced type $1 \mathrm{DM}$ were treated with metcarbatone, etcarbatone or styrylcarbatone (all compounds at doses $0.05 \mathrm{mg} \mathrm{kg}^{-1}$ or $0.5 \mathrm{mg} \mathrm{kg}^{-1}$ ) nine days after the DM approval. Gene expression levels in kidneys and blood were evaluated by quantitative RT-PCR; protein expression - immunohistochemically in kidneys, heart, sciatic nerve, and eyes; DNA breakage - by comet assay in nucleated blood cells. Induction of DM induced DNA breaks; metcarbatone and styrylcarbatone (low dose) alleviated this effect. Metcarbatone and etcarbatone up-regulated mRNA and protein of eNOS in kidneys of diabetic animals; etcarbatone also in myocardium. Etcarbatone reduced the expression of increased iNOS protein in myocardium, nerve, and kidneys. iNos gene expression was up-regulated in kidneys by etcarbatone and metcarbatone in diabetic animals. In blood, development of DM increased iNos gene expression; etcarbatone and metcarbatone normalised it. Etcarbatone up-regulated the expression of $\mathrm{H} 2 \mathrm{AX}$ in kidneys of diabetic animals but decreased the production of c-PARP1. Taken together, our data indicate that carbatonides might have a potential as drugs intended to treat DM complications.
\end{abstract}

KEY WORDS: 1,4-dihydropyridine derivatives; diabetes mellitus; DNA damage; free radical scavengers; nitric oxide synthases

New remedies for treatment of type one diabetes mellitus (T1DM) complications are sought among compounds with antioxidant activities $(1,2)$. Following this logic, we have chosen some representatives of group of 1,4-dihydropyridine (1,4-DHP) derivatives synthesised in the Latvian Institute of Organic Synthesis (see Table 1 for structures). These compounds did not manifest high $\mathrm{Ca}^{2+}$ channel blocker activity (3), however, they displayed antioxidant activities (4) and interfered with mitochondria by uncoupling respiration and phosphorylation (5). Some of these compounds manifested antidiabetic activities. For example, cerebrocrast promoted decrease of food intake (6), protected pancreatic cells from streptozotocin (STZ)-

Correspondence to: Kristīne Ošiņa, Institute of Biology of the University of Latvia, Miera Street 3, Salaspils, LV 2169, Latvia, phone +371 67944988, fax +37167944988, E-mail:kristine.osina@lu.lv induced damage and reduced glucose level in blood of animals with developed $\operatorname{DM}(7,8)$, and acted synergistically with insulin on heart functions and metabolism in diabetic rats (9). The same 1,4-DHP derivative and its analogues normalised nitric oxide (NO) production in diabetic animals and modified expression of genes involved in NO metabolism (10). Besides its antioxidant properties, 1,4DHP derivative AV-153 turns out to be a DNA repair enhancer (11) capable of interacting directly with DNA (12); cerebrocrast and its analogues manifest identical properties (10). We have shown that AV-153 down-regulates poly(ADP)ribose polymerase 1 (PARP1) and inducible NO synthase (iNOS) protein expression and increases the level of endothelial NO synthase (eNOS) protein and H2A histone family member X (H2afx) gene expression in kidneys of animals with experimental DM (13). Several 1,4-DHPs modify expression of proteasomal genes (14). Taken 
Table 1 Chemical structures of carbatonides [disodium-2,6-dimethyl-1,4-dihydropyridine-3,5-bis(carbonyloxyacetate) derivatives]

Compound Carbatone

Etcarbatone $\mathrm{C}_{2} \mathrm{H}_{5}$
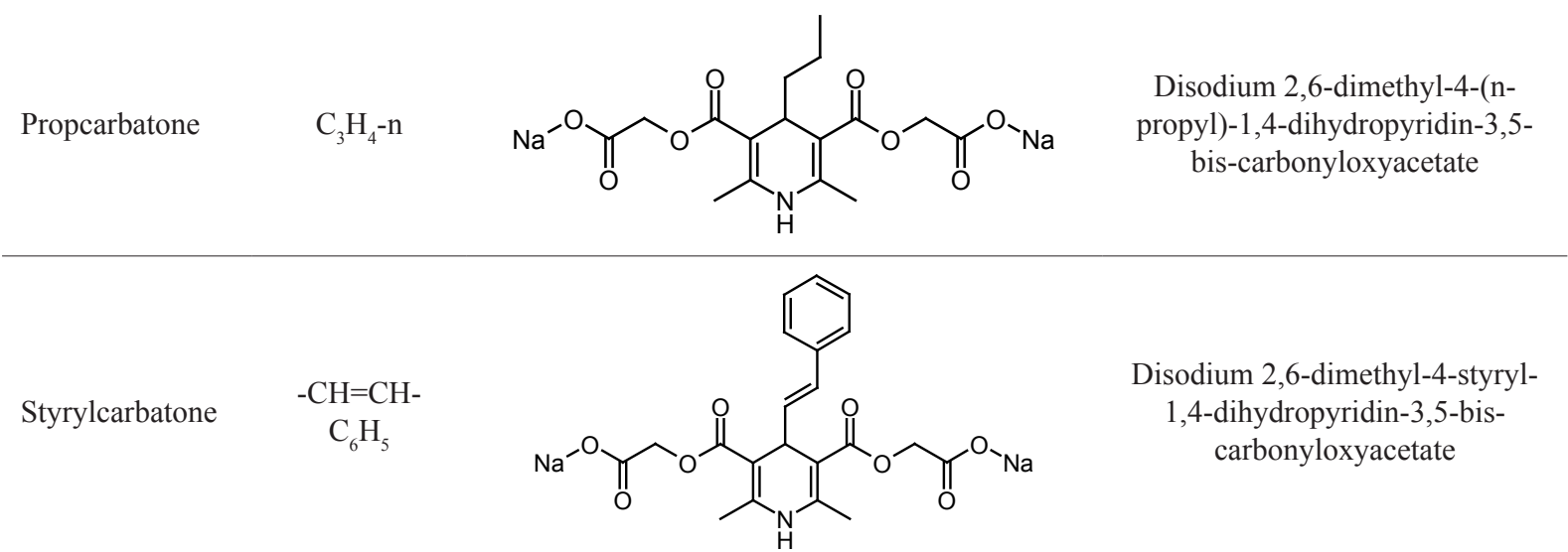

together, this group of 1,4-DHP derivatives appeared to be prospective for the study of their possible application as remedies against DM complications and should be studied further.

The aim of the present work was to test disodium-2,6dimethyl-1,4-dihydropyridine-3,5-bis(carbonyloxyacetate) derivatives (carbatonides) with different groups in position 4 by means of EPR spectroscopy for its capability to scavenge hydroxyl radical produced in the Fenton reaction, to protect DNA against above mentioned radicals in vitro, and to bind DNA. A series of in vivo experiments were conducted to study mRNA and protein expression levels in healthy animals and the expression of several proteins and genes involved in apoptosis, DNA repair, and free radical production in animals with STZ-induced diabetes mellitus. It is considered that impaired production of NO is a crucial point in development of DM complications. It is mainly due to the uncoupling of eNOS and overexpression of iNOS, as well as increased NO synthase-independent generation of NO by xanthine dehydrogenase (XDH) (10, 13 and references therein). This determined the choice of the abovementioned genes. Generation of DNA lesions and impaired DNA repair is also an important step in the pathogenesis of DM complications. The level of poly(ADP) ribose synthesis by PARPs characterises the intensity of the repair response to DNA lesions. This determined the choice of the PARP1 gene and protein study; moreover, the cleaved form of the protein is a sensitive apoptosis marker. H2AX histone, a sensitive marker of DNA double strand breaks, was chosen also to characterise the level of DNA lesions (13 and references therein).

\section{MATERIALS AND METHODS}

\section{Chemicals}

Carbatone, metcarbatone, etcarbatone, propcarbatone, and styrylcarbatone (J-9-125) (Table 1) were synthesised 
at the Latvian Institute of Organic Synthesis and characterised by usual physico-chemical methods: ${ }^{1} \mathrm{H}-\mathrm{NMR},{ }^{13} \mathrm{C}-\mathrm{NMR}$, IR spectroscopy, as well as LC-MS and elemental analysis. STZ, citric acid, EDTA, ferrous sulphate, hydrogen peroxide, low-melting agarose, $\mathrm{NaCl}$, $\mathrm{NaOH}$, Tris base, 5,5-dimethylpyrroline-N-oxide, ethidium bromide, and TRI reagent were purchased from SigmaAldrich Chemie (Taufkirchen, Germany).

In vitro experiments

\section{Fenton reaction - ESR measurements}

Trapping of the hydroxyl radical was performed by 5,5-dimethylpyrroline-N-oxide (DMPO)-spin trap. EPR spectra of the spin trap and radical complex were recorded at room temperature using a Bruker D-200 ER spectrometer (IBM Bruker Ltd, Coventry, UK), operating at X-band with a TM cavity and capillary tube. For the Fenton reaction $\left(\mathrm{Fe}^{2+}+\mathrm{H}_{2} \mathrm{O}_{2} \rightarrow \mathrm{Fe}^{3+}+\cdot \mathrm{OH}+\mathrm{OH}^{-}\right)$, reactants containing $80 \mathrm{mmol} \mathrm{L}^{-1}$ DMPO, $250 \mu \mathrm{mol} \mathrm{\textrm {L } ^ { - 1 }}$ ferrous sulphate, $250 \mu \mathrm{mol} \mathrm{L}^{-1} \mathrm{H}_{2} \mathrm{O}_{2}$ and $20 \mu \mathrm{L}$ of 1,4-DHP were mixed in a test tube to a final volume of $100 \mu \mathrm{L}$ and the reaction mixture was then transferred to a capillary tube for the measurement of the EPR signal. The EPR spectrometer settings were as follows: modulation frequency $-100 \mathrm{kHz}$; X band microwave frequency $-9.5 \mathrm{GHz}$; microwave power 0-15 mW (milliwatts); modulation amplitude - $1.0 \mathrm{G}$ (gauss); time constant $-160 \mathrm{~s}$; scan time $-200 \mathrm{~s}$, and receiver gain $-1 \times 10^{5}(15)$.

\section{UV/VIS spectroscopic measurements and fluorescence assays}

UV-VIS spectra of the tested compounds were recorded on a Perkin Elmer Lambda 25 UV/VIS spectrophotometer in the absence of DNA and presence of increasing amounts of DNA in $5 \mathrm{mmol} \mathrm{L}^{-1} \mathrm{NaCl}$ and $5 \mathrm{mmol} \mathrm{L}^{-1}$ Tris $\mathrm{HCl}$ at $\mathrm{pH}$ 7. The solution of the tested compound $(25 \mu \mathrm{mol} \mathrm{L}-1)$ was diluted out of $1 \mathrm{mmol} \mathrm{L}^{-1}$ stock solution in the buffer in a quartz cell $(1 \mathrm{~mL})$. The reference cell was filled with $1 \mathrm{~mL}$ of buffer. The mixture was mixed thoroughly and titrated with $7.48 \mathrm{mmol} \mathrm{L}^{-1}$ of sonicated pTZ57R plasmid DNA solution, $5 \mu \mathrm{L}$ each time to both sample and reference cells. Spectra were recorded in 400-200 nm interval at room temperature (10). Spectrofluorimetric analyses were performed on a Fluoromax-3 (Horiba JOBIN YVON, Edison, NJ, USA) device. The fluorescence spectra of $25 \mu \mathrm{mol} \mathrm{L}{ }^{-1}$ solution of compounds in $50 \mathrm{mmol} \mathrm{L}^{-1} \mathrm{NaCl}$ and $5 \mathrm{mmol} \mathrm{L}^{-1}$ Tris $\mathrm{HCl}$ at $\mathrm{pH} 7$ were recorded in the range of 365-600 nm at excitation wavelength of $350 \mathrm{~nm}$ or $360 \mathrm{~nm}$. DNA concentration was increased by $12.5 \mu \mathrm{mol}$ at each step until saturation was obtained in fluorescence spectroscopic experiments on ethidium bromide extrusion from complex with DNA. The complex of plasmid DNA $(74.8 \mu \mathrm{mol} \mathrm{L}-1)$ and ethidium bromide $\left(1.26 \mu \mathrm{mol} \mathrm{L}^{-1}\right)$ was titrated with $8.3 \mu \mathrm{mol} \mathrm{L}^{-1}$ aliquots of $2.5 \mathrm{mmol} \mathrm{L}^{-1}$ solution of the compound. Measurements were carried out at room temperature in $50 \mathrm{mmol} \mathrm{L}^{-1} \mathrm{NaCl}$ and $5 \mathrm{mmol} \mathrm{L}^{-1}$ Tris $\mathrm{HCl}$ at pH 7 using $1 \mathrm{~cm}$ cuvette. Excitation wavelength was $335 \mathrm{~nm}$, fluorescence was measured at $600 \mathrm{~nm}$. Binding constants were calculated as described $(10,12)$.

\section{In vivo experiments}

\section{Animals}

This study was approved by the Animal Ethics Committee of the Food and Veterinary Service (Riga, Latvia) and it was carried out according to the guidelines of the Directive 86/609/EEC "European Convention for the Protection of Vertebrate Animals Used for Experimental and other Scientific Purposes" (1986). Wistar male rats $(215.0 \pm 5.6 \mathrm{~g})$ were purchased from the Laboratory of Experimental Animals, Riga Stradins University, Riga, Latvia. Animals were kept at a temperature of $22 \pm 0.5{ }^{\circ} \mathrm{C}$ with a 12-h light/dark cycle and fed with a standard laboratory diet.

\section{Experiment design}

In total, 128 rats were used in the study. T1DM was induced by STZ injection via the tail vein $\left(50 \mathrm{mg} \mathrm{kg}^{-1}\right.$,

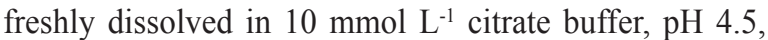
injection volume $0.2-0.25 \mathrm{~mL}$ ). Control rats received $0.2 \mathrm{~mL}$ of $0.9 \% \mathrm{NaCl}$ via the tail vein. Diabetes was certified by measuring glucose level in tail vein blood of the fed rats in the morning 48 hours after the induction using a portative glucometer MediSense OptiumXceed (Abbott Diagnostics Ltd, Maidenhead, UK). Animals with blood glucose $>13.89 \mathrm{mmol} \mathrm{L}^{-1}\left(250 \mathrm{mg} \mathrm{dL}^{-1}\right)$ were used in experiments. The experiment was performed at day nine after confirmation of DM. Rats were divided in two big groups: control group (animals without DM) and STZ group (animals with induced DM). Each group was divided in seven subgroups: animals with no treatment, animals treated with either metcarbatone at low dose $\left(0.05 \mathrm{mg} \mathrm{kg}^{-1}\right.$ p.o. of metcarbatone for three days), metcarbatone at high dose ( $0.5 \mathrm{mg} \mathrm{kg}^{-1}$, similarly), etcarabtone at low dose, etcarbatone at high dose, styrylcarbatone at low dose or styrylcarbatone at high dose. Each group contained at least three animals. After the treatment course glucose was measured, then the rats were euthanised, kidney and blood samples of all animals were taken and frozen in liquid nitrogen for RNA extraction. Samples of heart, kidneys, eyes and sciatic nerve of animals in groups of untreated animals and animals treated with metcarbatone and etcarbatone were fixed for immunochemistry.

\section{Tissue processing and immunohistochemical examination}

Rat kidney, heart, eye and sciatic nerve tissue specimens were processed and examined essentially as described (10). Tissue specimens were fixed in $10 \%$ neutral buffered formalin and embedded in paraffin. Specimens were cut in 
$5 \mu \mathrm{m}$ thick section on a rotary microtome and mounted on poly-lysine coated glass slide. The following antibodies were used: rabbit polyclonal eNOS antibody (AbCam, Cambridge, UK, ab 66127; dilution 1:100), rabbit polyclonal iNOS antibody (AbCam, ab 3523; dilution 1:200), anti-cleaved PARP1 rabbit monoclonal antibody (AbCam, ab32651, dilution 1:200), and rabbit polyclonal histone gamma-H2AX antibody (AbCam, ab11175, dilution 1:500). Bound antibodies were detected using the EnVision (DAKO, Glostrup, Denmark) reagent (30 min at room temperature). The immunoperoxidase reaction colour was developed by incubating the slides with diaminobenzidine for $7 \mathrm{~min}$. Each experiment included a negative control (mice tissues) omitting the primary antibody and positive controls (human tissues) - lung tissue and liver tissues for iNOS, liver and aorta tissues for eNOS and thyroid papillary carcinoma tissue for cleaved PARP1 and histone H2AX.

\section{Gene expression studies}

Gene expression studies were performed as described (10). Total RNA was isolated from kidneys and blood using TRI reagent and purified using DNA-free kit (Ambion, Austin, TX, USA). RNA quantity and purity were determined by spectrophotometry. The integrity of RNAs was monitored by gel electrophoresis and only specimens with well-pronounced rRNA bands were taken for reactions. To obtain cDNA, $2 \mu \mathrm{g}$ of RNA were reverse-transcribed using a random hexamer primer (RevertAid ${ }^{\mathrm{TM}}$ First Strand Synthesis Kit, Fermentas, Vilnius, Lithuania) (10). Primer s e quences for $i N o s$ gen e were 5'-GCTACACTTCCAACGCAACA-3' (forward primer) and 5'-CATGGTGAACACGTTCTTGG-3' (reverse primer). Primers for eNos gene were 5'-GAACCTGAGGGTGCCCAG-3' (forward primer) and 5'-TCCGATTCAACAGTGTCTCCT-3' (reverse primer). Primers for Parpl gene we e 5'-CGGAGAGGCTTTACCGAGTG-3' (forward primer) and 5'-GAACATGGGTGACTGCACCA-3' (reverse primer). Primers for H2afx gene were 5'-CGGTTTGTCTCCTGGCGTTT-3' (forward primer) and 5'-ACATCGTGTGCGAGGTAGAA-3' (reverse primer). Primers for xanthine deoxygenase gene $X d h$ were 5'-CGGACCCTGAAACAACACTT-3' (forward primer) and 5'-CAAGCAGGCATTGACAGAAA-3' (reverse p r i m e r). R N A - p o l y m e r a s e I I ( 5' - G C C A G A G T C T C C C AT G T G T T-3' and 5'-GTCGGTGGGACTCTGTTTGT-3', 135 bp) was chosen as a reference gene.

SYBR $^{\circledR}$ Green PCR Master Mix (Applied Biosystems, Foster City, CA, USA) was used for determination of gene expression. Amplification and detection of specific products were performed on a StepOne ${ }^{\mathrm{TM}}$ Real-Time PCR System (Applied Biosystems, Foster City, CA, USA) using the following temperature-time profile: one cycle of $95^{\circ} \mathrm{C}$ for $10 \mathrm{~min}$, and 40 cycles of $95^{\circ} \mathrm{C}$ for $15 \mathrm{sec}, 60{ }^{\circ} \mathrm{C}$ for $1 \mathrm{~min}$.
To check the specificity of the amplification products, the dissociation curve mode was used (one cycle at $95^{\circ} \mathrm{C}$ for $15 \mathrm{sec}, 60{ }^{\circ} \mathrm{C}$ for $1 \mathrm{~min}$, and $95^{\circ} \mathrm{C}$ for $15 \mathrm{sec}$ ).

\section{The single cell gel electrophoresis (comet assay)}

The comet assay was performed as described $(11,16)$ with minor modifications (17). Blood for the comet assay was taken from the tail vein into a plastic capillary with heparin (Microvette CB 300, Sarstedt, Germany). Next, $10 \mu \mathrm{L}$ of fresh heparinised blood were mixed with $120 \mu \mathrm{L}$ of prewarmed $\left(37^{\circ} \mathrm{C}\right) 1 \%$ low-melting agarose, $100 \mu \mathrm{L}$ of the mixture were placed on a microscope slide that had been pre-coated with $0.5 \%$ normal melting-point agarose. The cell membranes were lysed by keeping the slides in a cold lysing solution ( $\mathrm{pH} 10.0$ ) that contained $2.5 \mathrm{~mol} \mathrm{~L}^{-1} \mathrm{NaCl}$, 10 mmol L-1 $\mathrm{Na}_{2}$ EDTA, $10 \mathrm{mmol} \mathrm{L}^{-1}$ Tris, $1 \%$ Triton-X 100, $5 \%$ DMSO (Sigma-Aldrich, Germany), for at least $1 \mathrm{~h}$. Subsequently, the slides were placed in a horizontal tank filled with fresh electrophoresis buffer $\left(1 \mathrm{mmol} \mathrm{L}^{-1}\right.$ $\mathrm{Na}_{2}$ EDTA, $300 \mathrm{mmol} \mathrm{L}{ }^{-1} \mathrm{NaOH}, \mathrm{pH}$ 13.2) for $20 \mathrm{~min}$ to allow DNA to unwind. Then, horizontal electrophoresis was carried out for $20 \mathrm{~min}$ at $300 \mathrm{~mA}, 1 \mathrm{~V} \mathrm{~cm}^{-1}$ and $4{ }^{\circ} \mathrm{C}$. After electrophoresis, slides were washed twice for $5 \mathrm{~min}$ with $0.4 \mathrm{~mol} \mathrm{~L}^{-1}$ Tris buffer ( $\mathrm{pH} \mathrm{7.5)} \mathrm{for} \mathrm{neutralisation} \mathrm{and}$ then fixed in ice-cold $96 \%$ ethanol for $10 \mathrm{~min}$. Slides were dried and stained with ethidium bromide and analysed with a fluorescence microscope equipped with $515-560 \mathrm{~nm}$ excitation filter and $590 \mathrm{~nm}$ barrier filter. Cells were visually graded into five classes $\left(\mathrm{A}_{0}-\mathrm{A}_{4}\right)(11)$ from class 0 (undamaged, no discernible tail) to class 4 (almost all DNA in tail, insignificant head). The mean value of DNA damage (D) in arbitrary units was calculated as follows: $\mathrm{D}=\mathrm{A}_{1}+2 \times \mathrm{A}_{2}+3 \times \mathrm{A}_{3}+4 \times \mathrm{A}_{4}$.

\section{Statistics}

GraphPad Prism 6 software (San Diego, CA, USA) was used for statistical analysis. Results of the immunohistochemical data, real time PCR, and comet assay were analysed by an unpaired t test with Welch's correction and two-way ANOVA followed by Dunnett's multiple comparisons test. Data are presented as means \pm SEM.

\section{RESULTS}

\section{Radical scavenging - EPR measurements}

The ability of the 1,4-DHPs to scavenge the $\mathrm{OH}$ radical produced in the Fenton reaction was tested by the ESR method. The signals of the second compound of EPR spectra were measured on the $3^{\text {rd }}\left(\mathrm{I}_{3}\right)$ and $5^{\text {th }} \min \left(\mathrm{I}_{5}\right)$ and the difference between them $\mathrm{I}_{3}-\mathrm{I}_{5}$ was calculated (Fig. 1; A). The scavengers of $\mathrm{OH}$ radicals should increase the difference between $\mathrm{I}_{3}$ and $\mathrm{I}_{5}$. Representative kinetics of the decrease in the EPR signal intensity is shown in Figure 1B. Compounds were given at $1 \mathrm{mmol} \mathrm{L}^{-1}$ concentration. 
A $\left[\times 10^{-6}\right.$
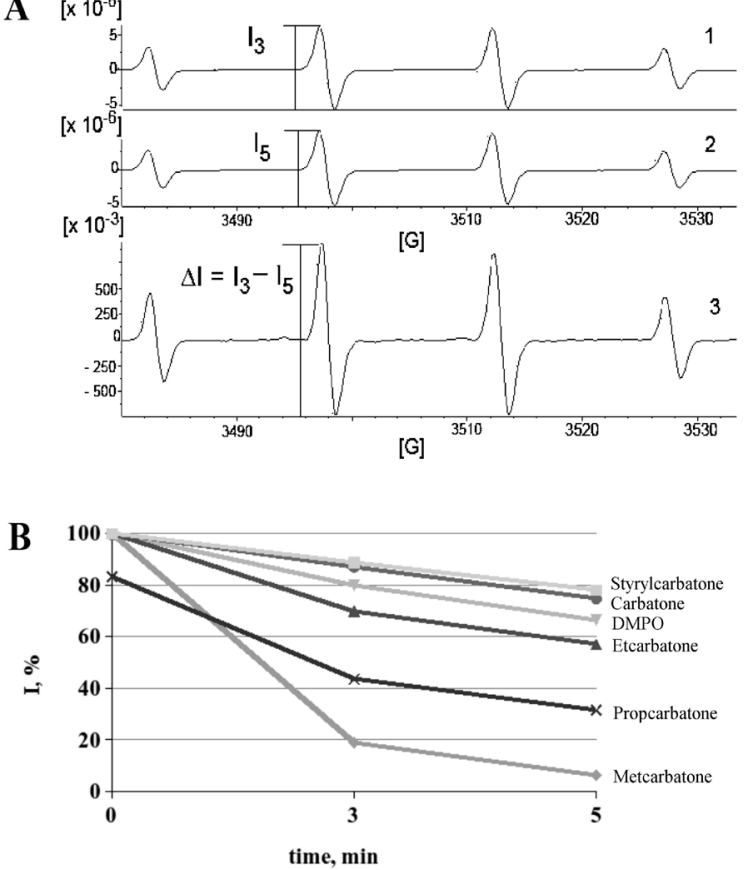

Figure $1 A$ - EPR spectra of DMPO-OH radicals generated in the Fenton reaction in presence of DMPO. 1 - EPR spectra of DMPO-OH radicals 3 min after mixing the components for the Fenton reaction. 2 - EPR spectra of DMPO-OH radicals 5 min after mixing the components for the Fenton reaction. $I_{3}$ and $I_{5}$ intensities of EPR signals used for the quantification of DMPO-OH radicals in the corresponding time. 3 -difference between $3 \mathrm{~min}$ and 5 min spectra indicating a decrease in the signal intensity and lack of generation of other radicals. $B$ - time of decrease in the intensity of DMPO-OH radical spectra, percent compared to the initial point

Carbatone did not scavenge the hydroxyl radical produced in the Fenton reaction, metcarbatone was an effective scavenger (radical concentration decreased up to $31.4 \%$ compared to the control, DMPO alone). Etcarbatone was less effective (up to $98.3 \%$ ); efficiency of propcarbatone was better than that of etcarbatone (86.4\%), but worse compared to metcarbatone. The scavenging efficiency of metcarbatone was dependent on the concentration: $0.5 \mathrm{mmol} \mathrm{L}^{-1}$ decreased the radical concentration up to $84.4 \%$ of the radical; when given at concentrations 0.2 or $0.1 \mathrm{mmol} \mathrm{L}^{-1}$ the compound was not effective (not shown). Styrylcarbatone even favoured the radicals' generation up to $106 \%$

\section{DNA binding}

The UV/VIS spectra of carbatone and propcarbatone are given in Figure 2, panel A. Other spectra are not shown. All the carbatonides absorbed light in the UV part of spectrum with a maximum at $235 \mathrm{~nm}$ and in the visible part of spectrum with a maximum at $380 \mathrm{~nm}$ for carbatone and at $355 \mathrm{~nm}$ for other carbatonides. In the UV/VIS titration assay carbatone, metcarbatone, etcarbatone, and propcarbatone manifested a slight hypochromic effect when interacting with DNA. Binding constants were $1.09 \times 10^{2}$ for carbatone, $0.82 \times 10^{2}$ for metcarbatone, $0.54 \times 10^{2}$ for etcarbatone, and $1.11 \times 10^{2}$ for propcarbatone. Unlike other carbatonides, styrylcarbatone manifested a hyperchromic effect in the presence of DNA (not shown), its affinity to DNA was higher compared to other carbatonides $\left(\mathrm{K}=1.9 \times 10^{3} \mathrm{~L} \mathrm{~mol}^{-1}\right)$. When irradiated with excitation light at $360 \mathrm{~nm}$, all five compounds emitted fluorescence with a maximum at $450 \mathrm{~nm}$. Interestingly, in the presence of DNA, fluorescence of carbatone and propcarbatone (not shown) was increased; on the contrary, DNA quenched fluorescence of metcarbatone (not shown), etcarbatone and styrylcarbatone (Stern-Volmer quenching constants were $3.8 \times 10^{2} \mathrm{~L} \mathrm{~mol}^{-1}$, $9.5 \times 10^{2} \mathrm{~L} \mathrm{~mol}^{-1}$ and $1.4 \times 10^{4} \mathrm{~L} \mathrm{~mol}^{-1}$, respectively; Figure 2, panel B). Styrylcarbatone intercalates the DNA molecule as it effectively decreased fluorescence of $74.8 \mu \mathrm{mol} \mathrm{L}^{-1}$ DNA and $1.26 \mu \mathrm{mol} \mathrm{L}^{-1}$ ethidium bromide complex - up to $70 \%$ after 16 additions of $10 \mu \mathrm{mol} \mathrm{L}^{-1}$ of the compound to the complex (Figure 2, panel C).
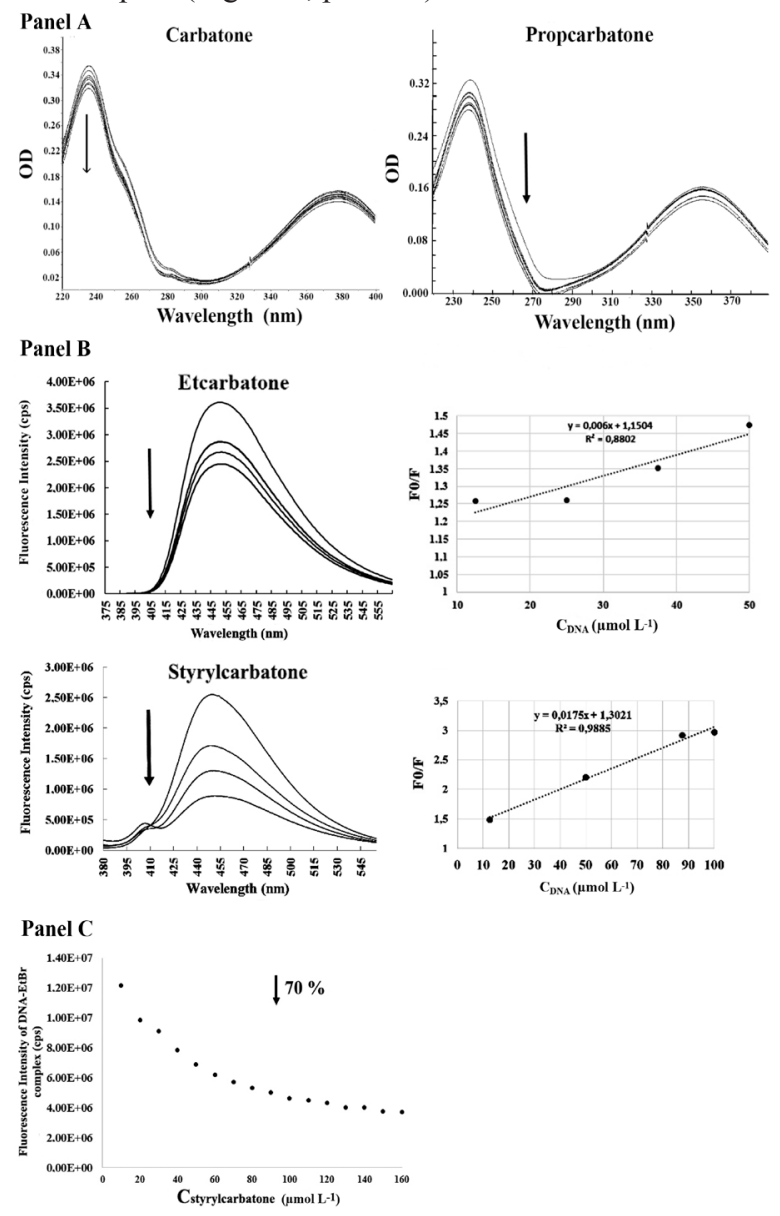

Figure 2 DNA binding of assays. (Panel A) UV/VIS spectroscopy. Plasmid DNA solution, $10 \mu \mathrm{mol} L^{-1}$ each time, was added to both sample and reference cells. (Panel B) Fluorescence spectra of carbatonides with excitation at $\lambda=360 \mathrm{~nm}$ (etcarbatone) and $\lambda=350 \mathrm{~nm}$ (styrylcarbatone) in absence and presence of different concentrations of sonicated pTZ57R plasmid DNA. Carbatonide concentration was $25 \mu \mathrm{mol} \mathrm{L} L^{-1}$, DNA concentration was increased by $12.5 \mu \mathrm{mol} L^{-1}$ at each step until saturation. (Panel $C$ ) Fluorescence quenching plot of the ethidium bromide-pTZ57R plasmid DNA complex as a function of styrylcarbatone concentration 


\section{Gene and protein expression studies}

Styrylcarbatone, metcarbatone, and etcarbatone were chosen for the in vivo studies. These compounds did not produce the hypoglycaemic effect (not shown). The impact of these compounds on the expression of several genes and proteins involved in NO production and DNA repair were tested in the kidneys of normal and diabetic animals. The expression of genes was also monitored in blood samples. Besides kidneys, immunohistochemical studies were performed also on heart, nerve, and eye tissues.

The expression of the Parpl gene (a marker of DNA repair), cleaved PARP1 protein (a marker of apoptosis), both proteins and genes of histone H2AX (DNA breakage marker) and two NO synthases (iNOS and eNOS) as well as $X d h$ gene (NO producing enzyme), were monitored. The quantified data of immunohistochemistry and real time PCR for kidneys are given in Tables 2-5.

\section{Parp1 gene}

We could not detect any significant differences in Parp1 gene expression in kidneys of intact rats and animals with STZ diabetes mellitus (Table 2). However, the administration of styrylcarbatone, etcarbatone, and metcarbatone at both doses caused a highly significant more than two-fold increase $(P<0.001)$ of the Parp 1 gene expression in kidneys of intact animals. When administered to diabetic animals, all the three compounds, except etcarbatone at high dose, also caused a strong increase in the gene expression $(P<0.01)$.

In blood cells, diabetes induction was followed by a strong, almost two-fold, increase in Parpl gene expression $(P=0.003)$. Both doses of etcarbatone attenuated the increase $(P<0.001)$. However, styrylcarbatone and metcarbatone were not effective (Table 2$)$.

\section{Cleaved PARP1 (c-PARP1) protein}

Development of the STZ-induced diabetes mellitus significantly increased the number of cells positive for c-PARP1 protein, a marker of apoptosis, in kidney tissue $(P=0.004)$. Metcarbatone did not modify the expression of the enzyme in diabetic kidneys, while administration of etcarbatone at both doses decreased the number of cells positive for c-PARP1 in diabetic kidneys $(P<0.001)$, although the compound upregulated the expression of the protein in kidneys of intact animals $(P<0.05)$ (Table 3$)$.

In heart tissues, c-PARP 1 was detected in cardiomyocytes, in some inflammatory interstitial cells, and around blood vessels (Figure 3). Development of diabetes mellitus caused a three-fold increase in the cells positive for c-PARP1 protein in myocardium $(P=0.025)$. The number of apoptotic cells was normalised by etcarbatone at both doses $(P<0.01)$ and low dose of metcarbatone $(P=0.018)$. In the sciatic nerve, the c-PARP1 protein was noticed in Schwann's cells and in the inflammatory cells around nerve sheaths (not shown). The three-fold increase $(P=0.009)$ in

\section{c-PARP1, myocardium}
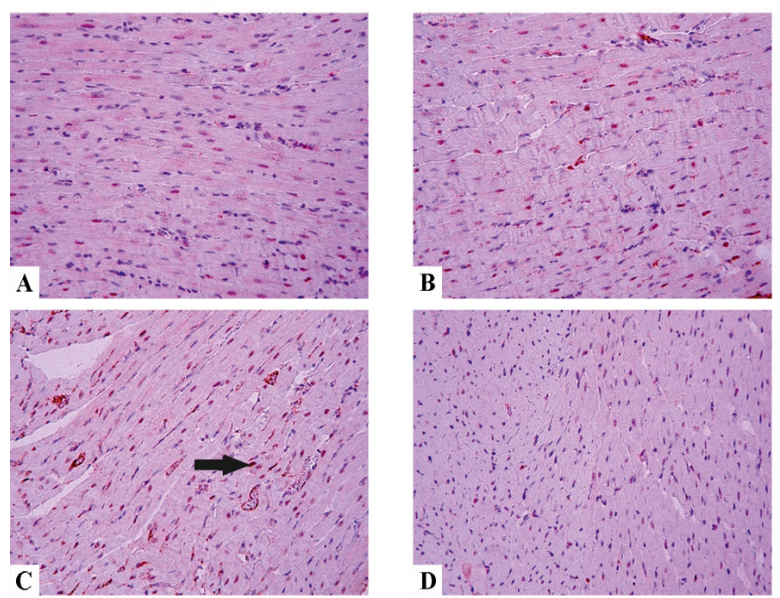

\section{H2AX, kidney}
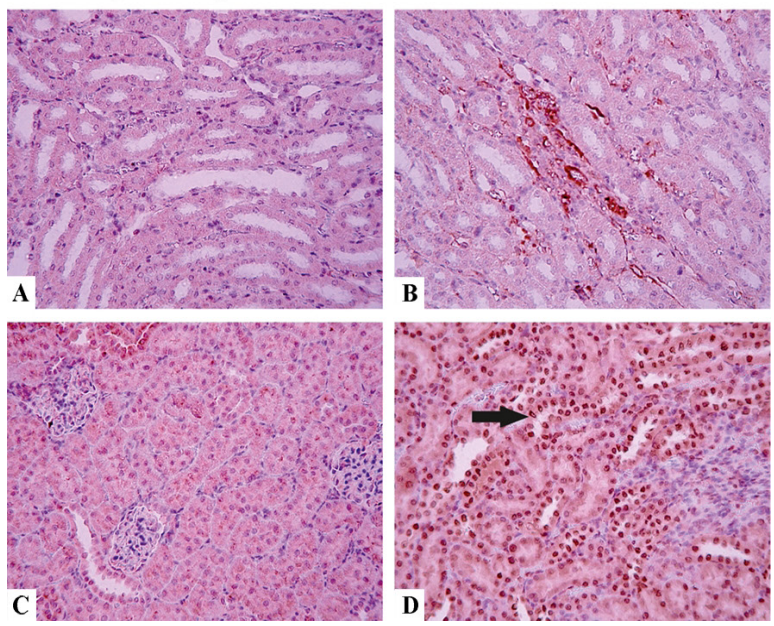

Figure 3 Tissue distribution of apoptosis and DNA breakage markers. Upper panel: c-PARP1 expression in the myocardium. Immunohistochemical staining method, magnification $\times 200$. A control, B - etcarbatone at $0.05 \mathrm{mg} \mathrm{kg}^{-1}, C$ - STZ (streptozotocin), $D$ - STZ+etcarbatone at $0.05 \mathrm{mg} \mathrm{kg}^{-1}$. Arrow indicates positively stained cells. Lower panel: H2AX expression in the kidney tissue. Immunohistochemical staining method, magnification $\times 200$. A control, B-etcarbatone at $0.05 \mathrm{mg} \mathrm{kg}^{-1}, C$-STZ, D-STZ+etcarbatone at $0.05 \mathrm{mg} \mathrm{kg}^{-1}$. Arrow indicates positively stained cells

the number of cells positive for this apoptotic protein following DM development was normalised by etcarbatone at both doses $(P<0.001)$; metcarbatone did not produce any impact on the number of apoptotic cells. In eye tissues, there was also a three-fold increase $(P=0.005)$ of c-PARP1 positive cells after induction of diabetes; both doses of etcarbatone increased it even more $(P<0.001)$ but metcarbatone showed no effect (Table 3 ).

\section{Histone H2AX and H2afx gene}

Numerical data are presented in Tables 2 and 3, microphotographs - in Figure 3. In kidneys, expression of H2AX was observed in proximal and distal canaliculi, in glomeruli, and blood vessel walls (Figure 3). The expression of this marker of DNA breakage on gene level did not 
Table 2 Effects of carbatonides on expression of Parp1 and $\mathrm{H} 2 \mathrm{afx}$ genes in kidneys and blood of control and diabetic rats

\begin{tabular}{|c|c|c|c|c|}
\hline & $\begin{array}{l}\text { Kidneys } \\
\text { Parp1 }\end{array}$ & $\begin{array}{l}\text { Kidneys } \\
\text { H2afx }\end{array}$ & $\begin{array}{l}\text { Blood } \\
\text { Parp1 }\end{array}$ & $\begin{array}{l}\text { Blood } \\
\text { H2afx }\end{array}$ \\
\hline Control & $\begin{array}{c}0.68 \pm 0.05 \\
n=11\end{array}$ & $\begin{array}{c}0.20 \pm 0.02 \\
\mathrm{n}=11\end{array}$ & $\begin{array}{c}0.055 \pm 0.007 \\
\mathrm{n}=10\end{array}$ & $\begin{array}{c}0.034 \pm 0.006 \\
\mathrm{n}=12\end{array}$ \\
\hline STZ & $\begin{aligned} 0.63 & \pm 0.04 \\
n & =9\end{aligned}$ & $\begin{array}{c}0.21 \pm 0.02 \\
\mathrm{n}=11\end{array}$ & $\begin{array}{c}0.089 \pm 0.010 \\
\mathrm{n}=15^{*}\end{array}$ & $\begin{array}{c}0.056 \pm 0.007 \\
\mathrm{n}=15^{*}\end{array}$ \\
\hline Metcarbatone $0.05 \mathrm{mg} \mathrm{kg}^{-1}$ & $\begin{array}{c}1.27 \pm 0.19 \\
\mathrm{n}=4 * * *\end{array}$ & $\begin{array}{c}0.19 \pm 0.02 \\
n=4\end{array}$ & $\begin{array}{c}0.032 \pm 0.009 \\
n=4\end{array}$ & $\begin{array}{c}0.027 \pm 0.006 \\
\mathrm{n}=4\end{array}$ \\
\hline Metcarbatone $0.5 \mathrm{mg} \mathrm{kg}^{-1}$ & $\begin{array}{c}1.19 \pm 0.05 \\
\mathrm{n}=4 * * *\end{array}$ & $\begin{array}{c}0.21 \pm 0.02 \\
n=4\end{array}$ & $\begin{aligned} 0.023 & \pm 0.002 \\
\mathrm{n} & =4\end{aligned}$ & $\begin{array}{c}0.019 \pm 0.001 \\
\mathrm{n}=4\end{array}$ \\
\hline $\begin{array}{l}\text { Metcarbatone } 0.05 \mathrm{mg} \mathrm{kg}^{-1} \\
+ \text { STZ }\end{array}$ & 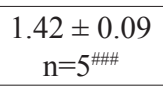 & $\begin{array}{c}0.21 \pm 0.01 \\
\mathrm{n}=5\end{array}$ & $\begin{array}{c}0.093 \pm 0.022 \\
\mathrm{n}=4\end{array}$ & $\begin{array}{c}0.041 \pm 0.006 \\
\mathrm{n}=4\end{array}$ \\
\hline $\begin{array}{l}\text { Metcarbatone } 0.5 \mathrm{mg} \mathrm{kg}^{-1} \\
+ \text { STZ }\end{array}$ & $\begin{array}{c}1.55 \pm 0.16 \\
\mathrm{n}=5^{\text {\#\# }}\end{array}$ & $\begin{array}{c}0.25 \pm 0.01 \\
\mathrm{n}=5\end{array}$ & $\begin{array}{c}0.086 \pm 0.017 \\
\mathrm{n}=5\end{array}$ & $\begin{array}{c}0.039 \pm 0.008 \\
\mathrm{n}=5\end{array}$ \\
\hline Etcarbatone $0.05 \mathrm{mg} \mathrm{kg}^{-1}$ & $\begin{array}{c}1.67 \pm 0.28 \\
\mathrm{n}=3 * * *\end{array}$ & $\begin{array}{c}0.24 \pm 0.04 \\
\mathrm{n}=3\end{array}$ & $\begin{array}{c}0.023 \pm 0.004 \\
n=3\end{array}$ & $\begin{array}{c}0.021 \pm 0.001 \\
\mathrm{n}=3\end{array}$ \\
\hline Etcarbatone $0.5 \mathrm{mg} \mathrm{kg}^{-1}$ & $\begin{array}{c}1.59 \pm 0.07 \\
\mathrm{n}=4 * * *\end{array}$ & $\begin{array}{c}0.20 \pm 0.02 \\
n=4\end{array}$ & $\begin{array}{c}0.036 \pm 0.002 \\
n=4\end{array}$ & $\begin{array}{c}0.024 \pm 0.007 \\
\mathrm{n}=4\end{array}$ \\
\hline $\begin{array}{l}\text { Etcarbatone } 0.05 \mathrm{mg} \mathrm{kg}^{-1} \\
+ \text { STZ }\end{array}$ & $\begin{array}{c}0.99 \pm 0.08 \\
n=5^{\# \#}\end{array}$ & $\begin{array}{c}0.24 \pm 0.03 \\
n=5\end{array}$ & $\begin{array}{c}0.036 \pm 0.009 \\
\mathrm{n}=5^{\# \#}\end{array}$ & $\begin{array}{c}0.034 \pm 0.006 \\
\mathrm{n}=5^{\#}\end{array}$ \\
\hline $\begin{array}{l}\text { Etcarbatone } 0.5 \mathrm{mg} \mathrm{kg}^{-1}+ \\
\text { STZ }\end{array}$ & $\begin{array}{c}0.85 \pm 0.10 \\
n=5\end{array}$ & $\begin{array}{c}0.18 \pm 0.02 \\
n=5\end{array}$ & $\begin{array}{c}0.033 \pm 0.004 \\
n=5^{\# \# \#}\end{array}$ & $\begin{array}{c}0.029 \pm 0.003 \\
\mathrm{n}=5^{\#}\end{array}$ \\
\hline $\begin{array}{l}\text { Styrylcarbatone } \\
0.05 \mathrm{mg} \mathrm{kg}^{-1}\end{array}$ & $\begin{array}{c}1.45 \pm 0.16 \\
\mathrm{n}=4 * * *\end{array}$ & $\begin{array}{c}0.24 \pm 0.02 \\
\mathrm{n}=4\end{array}$ & $\begin{array}{c}0.062 \pm 0.017 \\
\mathrm{n}=4\end{array}$ & $\begin{aligned} 0.033 & \pm 0.007 \\
\mathrm{n} & =4\end{aligned}$ \\
\hline $\begin{array}{l}\text { Styrylcarbatone } \\
0.5 \mathrm{mg} \mathrm{kg}^{-1}\end{array}$ & $\begin{array}{c}1.72 \pm 0.39 \\
\mathrm{n}=4 * * *\end{array}$ & $\begin{array}{c}0.28 \pm 0.09 \\
n=4\end{array}$ & $\begin{array}{c}0.055 \pm 0.010 \\
\mathrm{n}=3\end{array}$ & $\begin{array}{c}0.037 \pm 0.008 \\
\mathrm{n}=3\end{array}$ \\
\hline $\begin{array}{l}\text { Styrylcarbatone } \\
0.05 \mathrm{mg} \mathrm{kg}^{-1}+\mathrm{STZ}\end{array}$ & $\begin{array}{c}1.53 \pm 0.18 \\
\mathrm{n}=5^{\# \# \#}\end{array}$ & $\begin{array}{c}0.18 \pm 0.02 \\
n=5\end{array}$ & $\begin{array}{c}0.069 \pm 0.013 \\
\mathrm{n}=5\end{array}$ & $\begin{array}{c}0.034 \pm 0.006 \\
\mathrm{n}=5\end{array}$ \\
\hline $\begin{array}{l}\text { Styrylcarbatone } \\
0.5 \mathrm{mg} \mathrm{kg}^{-1}+\mathrm{STZ}\end{array}$ & $\begin{array}{c}2.37 \pm 0.11 \\
\mathrm{n}=5^{\text {\#\#\# }}\end{array}$ & $\begin{array}{c}0.28 \pm 0.02 \\
n=5\end{array}$ & $\begin{array}{c}0.110 \pm 0.022 \\
n=4\end{array}$ & $\begin{array}{c}0.049 \pm 0.009 \\
\mathrm{n}=4\end{array}$ \\
\hline
\end{tabular}

change in the kidneys of animals in any group, however, etcarbatone treatment at both doses up-regulated protein expression in diabetic animals $(P<0.01$, Table 3$)$. In diabetic animals, gene expression increased in blood $(P=0.002)$; etcarbatone at both doses normalised this parameter $(P<0.05)$; effects of styrylcarbatone and metcarbatone were not significant (Table 2). In the heart, the expression of histone was observed mostly in the nuclei of cardiomyocytes, to a lesser extent it was also seen in the nuclei of interstitial inflammatory cells and endocardium (not shown). Development of DM increased the number of histone H2AX positive cells in triplicate $(P=0.005)$. Treatment with etcarbatone at both doses enhanced this increase $(P<0.001)$. Metcarbatone at high dose decreased $(P=0.038)$ the expression of $\mathrm{H} 2 \mathrm{AX}$ in the nerve of intact rats but no other difference between the groups was observed in nerve and eye tissues (Table 3 ).

\section{iNOS (NOS2) enzyme and iNos (Nos2) gene}

Numerical data are presented in Tables 4 and 5. In kidneys, iNOS protein was expressed in glomeruli, canaliculi, stroma, and endothelium of blood vessels (not shown). Induction of diabetes caused a four-fold increase in the number of iNOS-positive cells $(P=0.002)$, etcarbatone at low dose significantly decreased the expression $(P=0.001)$ (Table 5), metcarbatone at low dose caused further upregulation $(P<0.001)$. Strikingly, the effects of the compounds on gene expression level in kidneys were adverse (Table 4): the development of diabetes produced a less drastic increase in the intensity of gene transcription $(P=0.044)$, etcarbatone at both doses produced an increase in intact animals $(P<0.01)$, and at low dose it increased $(P=0.003)$ the rate of transcription triggered by DM development. A similar effect was produced by metcarbatone at both doses $(P<0.001)$. An even stronger increase in gene transcription was observed in blood cells $(P=0.001)$, however, etcarbatone at both doses $(P=0.003)$ and metcarbatone at low dose $(P=0.01)$ attenuated the effect of DM but styrylcarbatone did not produce any effect. Immunohistochemical analysis of heart tissues revealed the expression of iNOS in cardiomyocytes, inflammatory cells, blood vessel walls, and stroma. The enzyme was detected in pericardium and endocardium but predominant expression was observed in myocardium (not shown). In DM model, the enzyme expression increased four-fold compared to the control group ( $P=0.003$; Table 5). A significant decrease in the effect was produced only by etcarbatone at low dose $(P=0.007)$. In the nerve, iNOS 


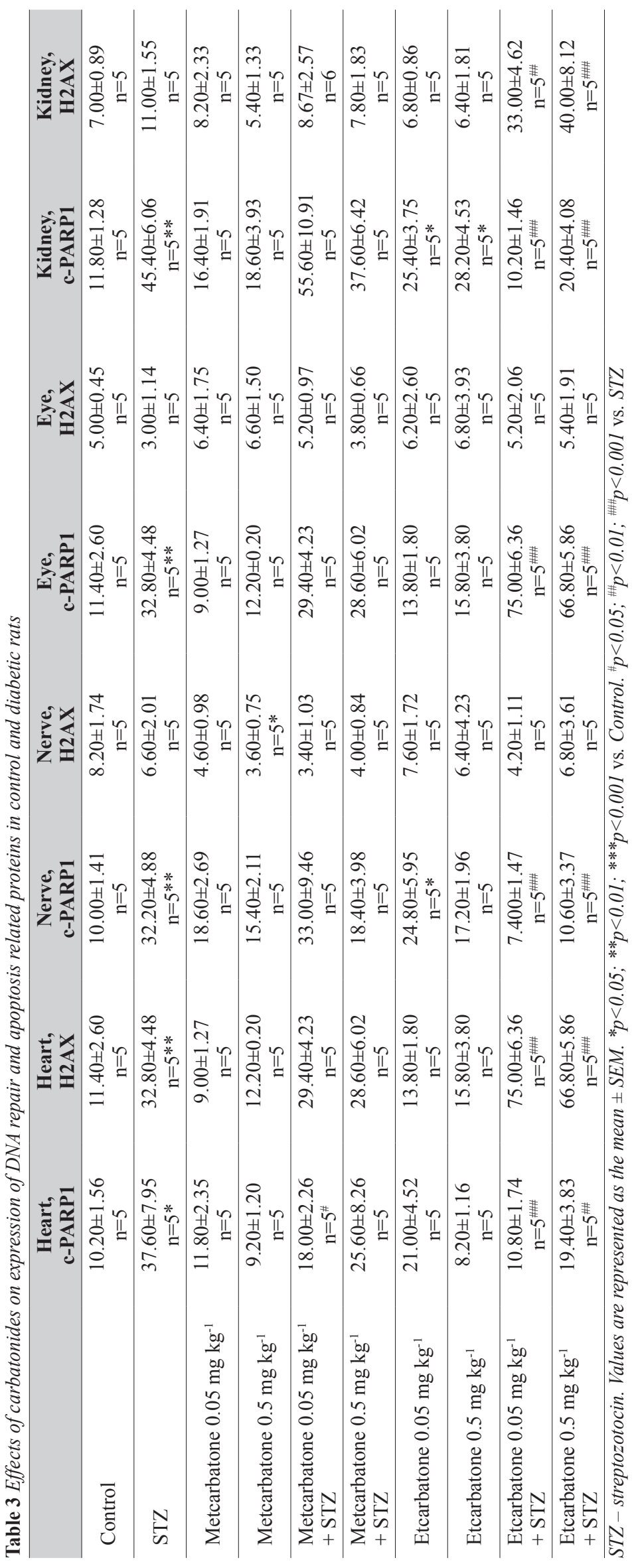


expression was observed in Schwann's cells (Figure 4); it increased in diabetic rats $(P=0.003)$. A low dose of etcarbatone increased the expression in control rats $(P<0.001)$, while both doses of etcarbatone decreased it in diabetic animals $(P<0.05)$. Development of DM caused qualitative changes in the distribution of iNOS-positive cells in eye tissues: in the eyes of intact animals the expression was detected mostly in the ciliary body, while in diabetic animals iNOS positive cells were observed also in the retina and vitreous body. The general number of positive cells also increased (Figure 4). Quantitatively, induction of diabetes increased iNOS expression $(P=0.021)$ but the compounds did not modify the expression significantly (Table 5)

\section{eNOS (NOS3) enzyme and eNos (Nos3) gene}

Data are presented in Tables 4 and 5. In heart tissues, eNOS expression was observed in the cytoplasm of

\section{iNOS, sciatic nerve}
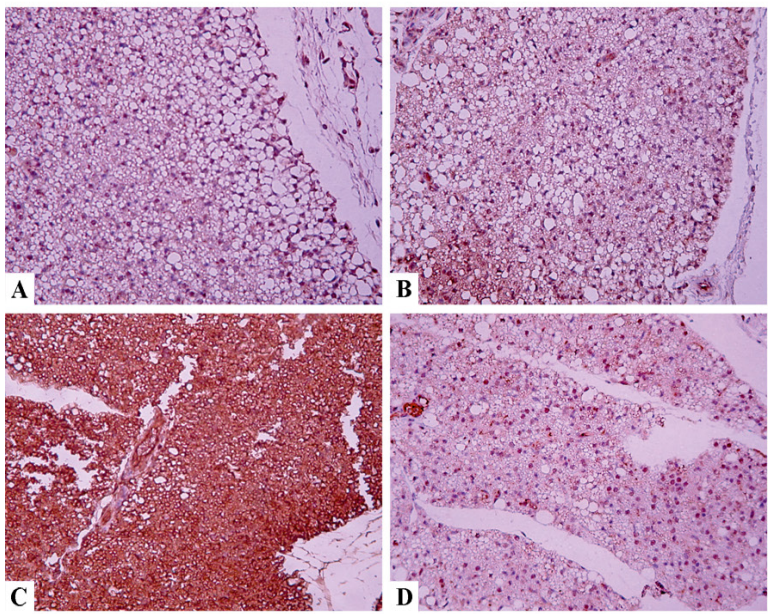

iNOS, eye
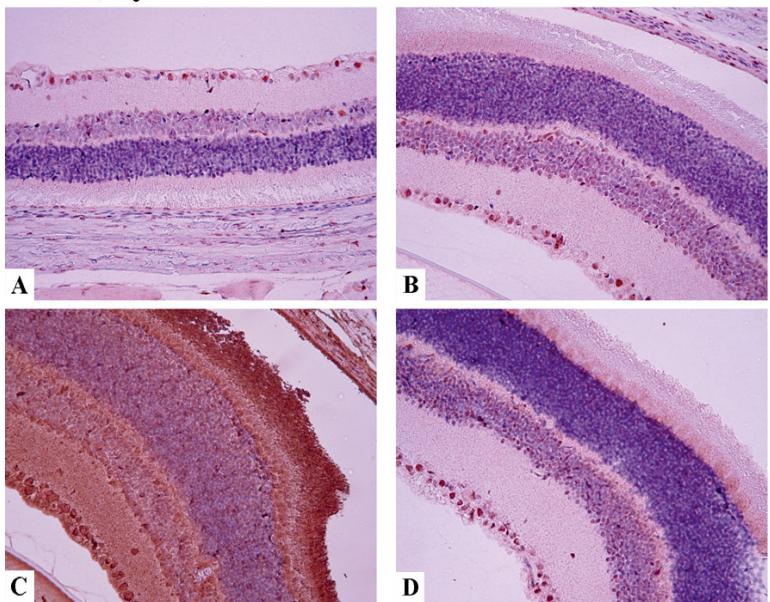

Figure 4 Tissue distribution of iNOS in organs of normal and diabetic rats. Upper panel: iNOS expression in the sciatic nerve tissue. Immunohistochemical staining method, magnification $\times$ 200. A - control, B - etcarbatone at $0.5 \mathrm{mg} \mathrm{kg}^{-1}, C$ - STZ (streptozotocin), D-STZ+etcarbatone $0.5 \mathrm{mg} \mathrm{kg-1}^{-1}$ Lower panel: iNOS expression in eye's tissue. Immunohistochemical staining method, magnification $\times 200$. A - control, B - etcarbatone at $0.5 \mathrm{mg} \mathrm{kg}^{-1}, C$ - STZ, D - STZ+etcarbatone at $0.5 \mathrm{mg} \mathrm{kg}^{-1}$ cardiomyocytes and inflammatory cells and in endothelium (not shown). We could not detect significant differences between control and STZ group, however, etcarbatone treatment at both doses up-regulated the protein expression in the heart of diabetic animals $(P<0.001)$. In kidney tissues, the enzyme was expressed in the cytoplasm of the cells forming proximal and distal canaliculi and in endothelium (not shown). Development of diabetes mellitus decreased the enzyme expression in kidneys compared to controls $(P<0.001)$. The expression was up-regulated by a low dose of metcarbatone $(P=0.016)$ and both doses of etacarbatone $(P<0.001$, Table 5). In nerve cells, eNOS protein expression increased by induction of diabetes $(P=0.008)$. It was normalised by both doses of etcarbatone $(P<0.01)$. In the eyes of intact animals, the expression of eNOS was restricted to the ciliar body; on the contrary, in diabetic animals it was observed not only in the ciliar body, but also in the retina, vitreous body, and inflammatory cells (not shown). Qualitative expansion of the expression was followed also by a numerical increase in eNOS-positive cells $(P<0.001)$.

The expression of eNos gene decreased in the kidneys of diabetic animals ( $P=0.04$, Table 4$)$. Both etcarbatone and metcarbatone at high doses increased the expression levels ( $P=0.009$ and $P=0.024$, respectively). Styrylcarbatone decreased gene expression by high dose in intact animals $(P=0.019)$ and by low dose in diabetic rats $(P=0.024)$.

\section{Xanthine deoxygenase gene (Xdh)}

Formerly we have demonstrated that the overall increase in NO production in STZ model of DM was due in part to NOS-independent production of NO by xanthine deoxygenase (10). Therefore, it was interesting to monitor the expression of this gene. Surprisingly, the increase in gene expression was detected only in the blood of diabetic animals ( $P=0.006$; Table 4$)$; styrylcarbatone and etcarbatone decreased it significantly (styrylcarbatone: $P=0.02$ for low dose; etcarbatone: $P=0.003$ for low dose, and $P=0.001$ for high dose). In kidneys, diabetes development did not change the expression of the gene, however, metcarbatone and styrylcarbatone up-regulated its expression in the kidneys of both control (metcarbatone: $P=0.04$ for low dose, $P=0.003$ for high dose; styrylcarbatone: $P<0.001$ for both doses) and diabetic animals (metcarbatone: $P<0.001$ for both doses, styrylcarbatone: $P<0.001$ for high dose). Etcarbatone produced similar effects; in the control group, it increased the expression of $X d h$ gene in the kidneys $(P<0.001$ for both doses $)$. In diabetic animals, both concentrations of etcarbatone up-regulated gene expression ( $P=0.001$ for low dose and $P=0.015$ for high dose).

\section{Comet assay}

Development of diabetes mellitus increased the level of DNA breakage in white blood cells $(P<0.001$, Figure 5). Surprisingly, metcarbatone, etcarbatone, and styrylcarbatone 


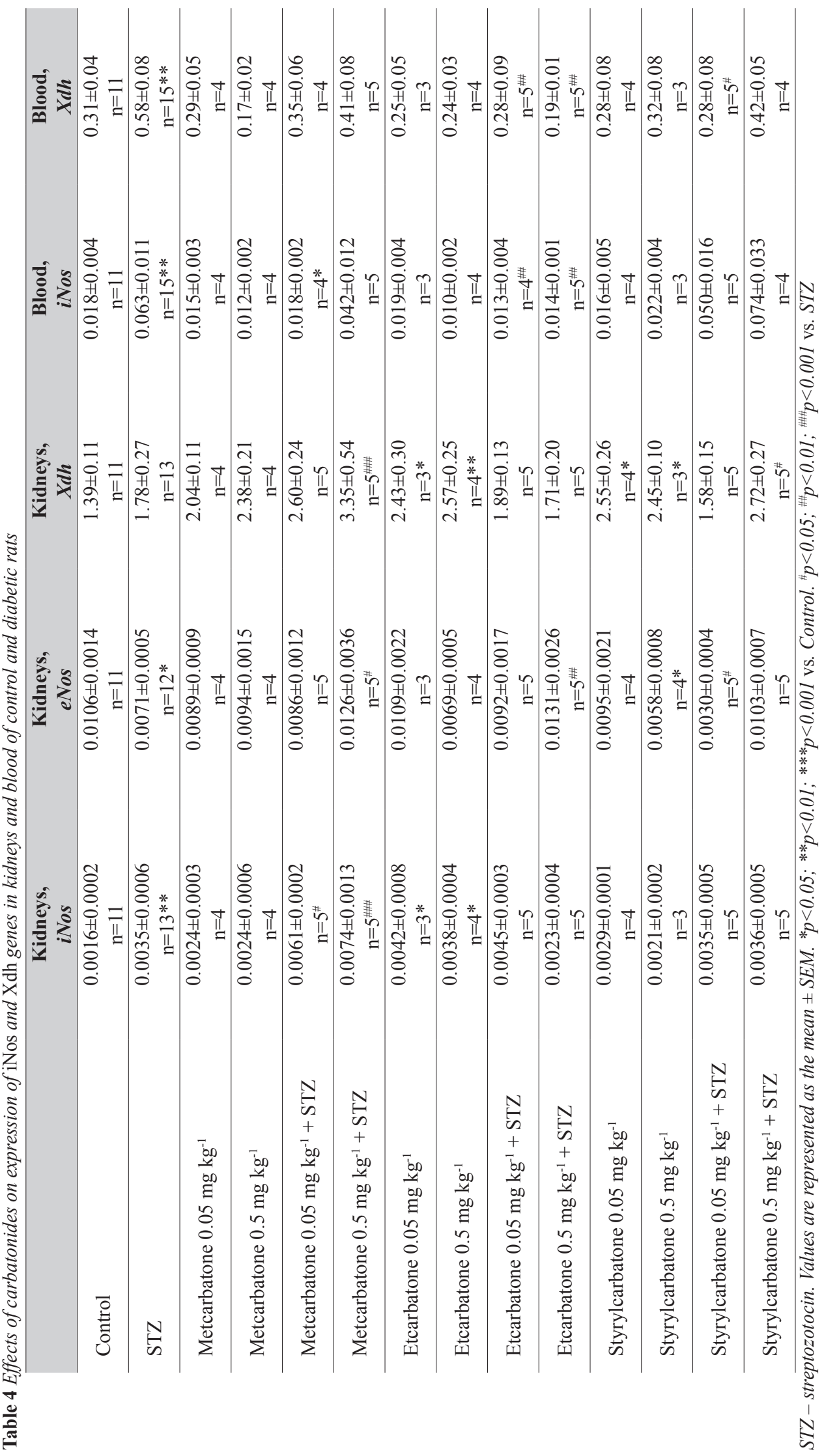


increased the level of DNA breakage in intact animals $(P<0.05)$; etcarbatone at high dose drastically increased DNA lesions also in diabetic animals $(P<0.001)$. However, metcarbatone at high dose $(P<0.001)$ and styrylcarbatone at low dose $(P=0.041)$ alleviated DNA damage level.

\section{DISCUSSION}

In the present study, we have performed in vitro and in vivo assays of several physicochemical properties and biological activities of carbatonides [disodium-2,6dimethyl-1,4-dihydropyridine-3,5-bis(carbonyloxyacetate) derivatives]. Our aim was to evaluate a probable use of these compounds for treatinfg DM complications. It turned out that replacing groups in position 4 could drastically modify the hydroxyl radical scavenging capability of the compounds; metcarbatone was much more effective compared to other compounds. Indeed, former studies indicate that radical-scavenging activity is really determined by position 4; a free carboxylic group in this position is considered to be the most favourable for radical scavenging. Our study shows that methyl group in this position also favours effective scavenging, at least under conditions of the chosen assay. However, radical scavenging activity of 1,4-DHPs strongly depends on the used system (4). Besides position 4 , the tested compounds were identical, thus, the considerations that electron donor substituents in positions 2 and 6 promote the quenching of oxidation, as well as stronger electron acceptors in positions 3 and 5 (4) cannot be applied to this study. All five compounds were capable of interacting with DNA, although their affinity to DNA was lower compared to other 1,4-DHPs $(10,12)$. The increase in fluorescence of carbatone and propcarbatone in the presence of DNA indicates a probable intercalation mechanism; the quenching of fluorescence by metcarbatone and etcarbatone indicates binding to the outer surface of
DNA molecule (18). Interestingly, styrylacarbatone manifested a higher affinity to DNA, although DNA quenched its fluorescence, ethidium bromide extrusion assay indicates intercalation. The compound might interact with DNA via two mechanisms - intercalation and minor groove binding. Probably, direct interactions of styrylacarbatone, etcarbatone, and metcarbatone with DNA are responsible for DNA damage in white blood cells of the intact animals observed after the administration of these compounds. DNA-damaging effects of antioxidant compounds are a frequently observed phenomenon, for example, antioxidant flavonoids induce oxidative DNA damage serving as temporary carriers of electrons received from transition metal ions that are relayed to oxygen molecules to subsequently generate superoxide and $\mathrm{H}_{2} \mathrm{O}_{2}$ (19). The DNA break reducing effect of metcarbatone in diabetic animals appears to be due to the radical scavenging activity of the compound, the weak scavenger etcarbatone even worsens the situation. This might be the cause of the increase in Parpl gene expression in intact animals as a consequence of a triggered DNA repair process.

The gene and protein expression studies revealed several effects of these compounds, which appear to be benevolent in condition of diabetes mellitus. Coherent up-regulation of both mRNA and protein of eNOS in the kidneys of diabetic animals triggered by both metcarbatone and etcarbatone appears to be a promising effect. In the myocardium, the decrease in the eNOS protein expression was not pronounced, still etcarbatone up-regulated it in diabetic animals. The uncoupling of the endothelial NO synthase with consequent production of superoxide radical and decrease in NO bioavailability is an important factor in the pathogenesis of complications of DM (20). To heal the complications, the uncoupling should be pharmacologically reduced (21) but eNOS protein expression should be stimulated; its activity should be

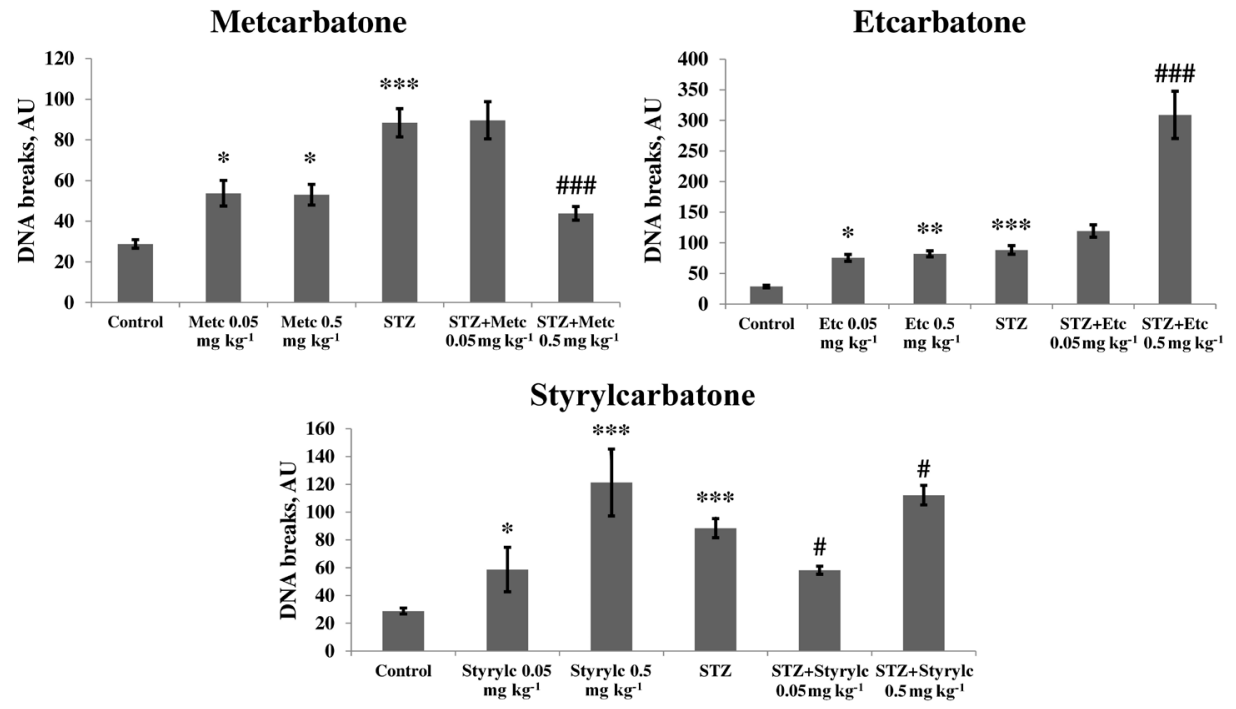

Figure 5 Effects of carbatonides on DNA integrity in white blood cells of normal and diabetic rats. STZ - streptozotocin; $n=3-17$. Values are represented as the mean \pm SEM. ${ }^{*} p<0.05 ;{ }^{* *} p<0.01 ;{ }^{* * *} p<0.001$ vs. Control. ${ }^{*} p<0.05 ;{ }^{*} p<0.001$ vs. STZ 


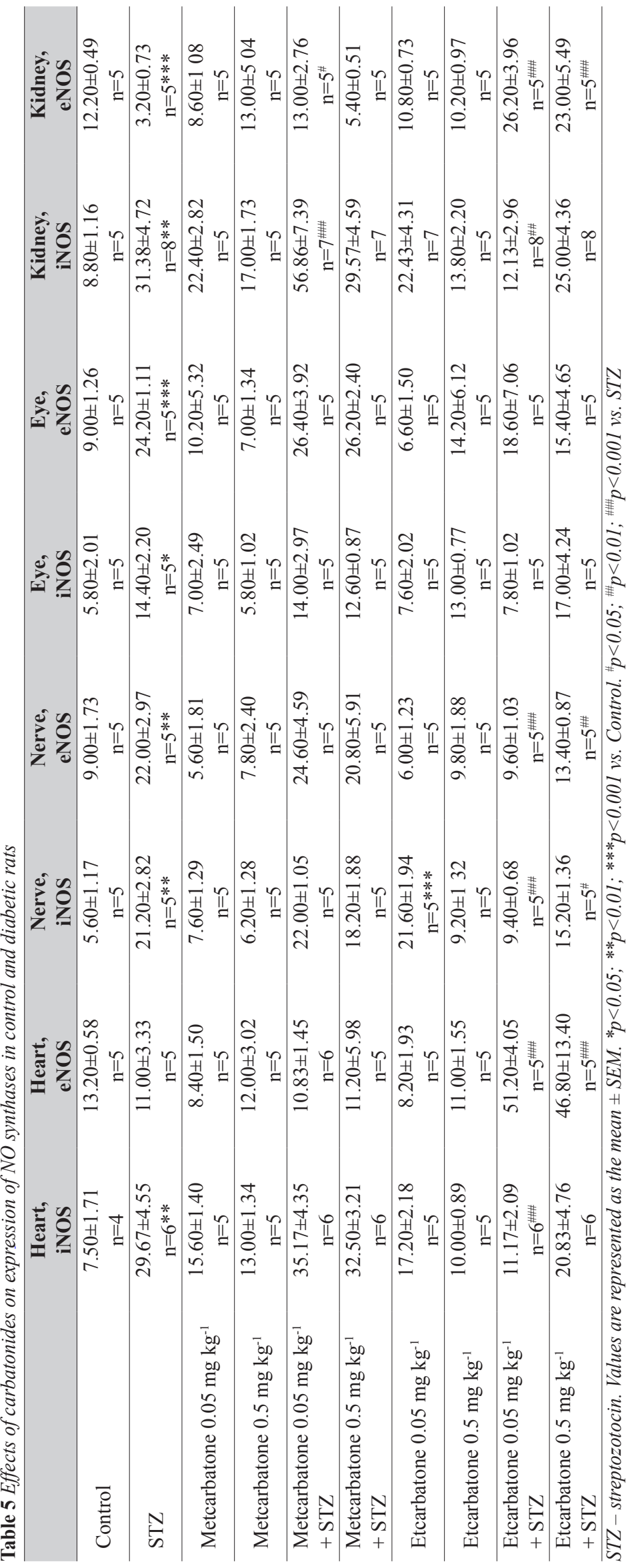


increased $(22,23)$. Up-regulation of eNOS favours sensitivity to insulin (24). Recent data indicate an important role of the regulation of eNOS expression in many processes, despite its "constitutive" nature (25). Thus, metcarbatone and etcarbatone appear to produce favourable effects aimed at preventing diabetic nephropathy and cardiomyopathy. However, our results on the eNOS expression in eye tissues contradict the published data, as a decrease in eNOS in diabetic retina was observed by others (26). It seems that the problem should be studied more in detail. A similar effect was observed in the sciatic nerve, eNOS was up-regulated in diabetic animals, etcarbatone down-regulated its expression. Our data contradict the findings of others (27) indicating a decrease in eNos expression in the sciatic nerve of mice predisposed to development of DM and an increase in expression as a result of the applied therapy. However, our model of DM was different and nerve tissue might have its peculiarities. For example, a simultaneous increase in $\mathrm{iNOS}$ and eNOS was observed in the hippocampus of animals subjected to hypoxia (28). On the contrary, in the paraventricular nucleus of animals with modelled insulin resistance, eNOS was down-regulated; expression of iNOS did not change (29). Others have also shown an increased as well as decreased expression of eNOS in different tissues of diabetic animals (30).

The observed increase in iNOS protein and iNos gene in the studied tissues of diabetic animals was in good correlation with published data. The increase in iNOS expression coupled to DM was reported for cardiomyocytes (31), blood vessels (32), retina (26), sciatic nerve (27) and kidneys (10). The ability to decrease iNOS expression is considered to be a positive feature in the search for remedies which are aimed to treat diabetes complications (33). Etcarbatone appears to be prospective from this point of view, as it reduced the expression of iNOS protein in heart, nerve, and kidney tissues, metcarbatone was ineffective. Concerning iNos gene expression, it was drastically upregulated in the kidneys of intact animals by styrylcarbatone and etcarbatone, stronger than in the DM model, and also up-regulated by metcarbatone and etcarbatone in diabetic animals. In blood, the increase in the $i$ Nos gene expression was triggered by the development of DM, and etcarbatone and metcarbatone normalised it. Thus, the effects on iNOS protein and gene expression are not coherent. This can be explained by the mechanisms of gene regulation: it is regulated post-transcriptionally to a large extent, maintenance of mRNA stability being very important (34, 35 ). The consequences of the observed outburst of mRNA expression could be levelled by post-transcriptional processing. Expression of the Parpl gene related to DNA repair and induced by DNA breakage resembled to a large extent the pattern of the $i$ Nos gene expression, co-ordinate expression of these genes is due to common Nrf-2 pathway of their regulation $(36,37)$. Thus, 1,4-DHPs increased the expression of the gene in kidneys of both intact and diabetic animals. 1,4-DHPs per se did not increase gene expression in blood, but etcarbatone attenuated the DM-triggered increase. Interestingly, the effects on $X d h$ gene expression were similar; the enzyme contributes to a large extent to NOS-independent NO production. Surprisingly, these data are in contradiction with the level of DNA breakage metcarbatone decreased it in diabetic animals but etcarbatone increased it. The marker of DNA double-strand breaks, the H2AX histone, did not react on DM induction in kidneys neither at gene, nor at protein expression levels. Surprisingly, etcarbatone up-regulated the expression of the protein, indicating the generation of double-strand DNA breaks. Discrepancy between mRNA and protein expression is not surprising, as the antibody detects the phosphorylated form of histone, generated after translation. It is phosphorylated by kinases such as ataxia telangiectasia mutated and ataxia telangiectasia mutated-Rad3-related in the PI3K pathway (38). However, we did observe an increased expression of the gene in blood cells, coherent with DNA breakage increase; perhaps, this reflects the fact that in lymphocytes the non-phosphorylated form of histone is also translocated to DNA breakage foci (39) triggering an increased transcription of the gene by feedback mechanism. Etcarbatone up-regulated also H2AX histone in myocardium. DNA double-strand breaks are usually associated with final stages of apoptosis; it was interesting to compare data on histone $\mathrm{H} 2 \mathrm{AX}$ expression and generation of cleaved PARP1, a marker of apoptosis. In kidneys, DM triggered a sharp increase in the c-PARP1 production; interestingly, etcarbatone treatment produced a strong anti-apoptotic effect. Thus, the DNA double-strand breaks produced by the compound should be repaired. The effects in myocardium were similar, again etcarbatone produced an anti-apoptotic effect, and thus $\mathrm{H} 2 \mathrm{AX}$ expression indicates the generation of reparable doublestrand breaks formed prior to apoptosis. Action of etcarbatone in the sciatic nerve is also anti-apoptotic; unfortunately, it is pro-apoptotic in eye tissues.

Taken together, our data indicate that derivatives of disodium-2,6-dimethyl-1,4-dihydropyridine-3,5bis(carbonyloxyacetate) appear to be a prospective compound group for the development of drugs aimed to treat DM complications like diabetic nephropathy, cardiomyopathy, and neuropathy. Etcarbatone appears to be the most prospective due to its ability to down-regulate iNOS, up-regulate eNOS, and prevent apoptosis in kidneys, hearts, and nerves of organisms suffering of hyperglycaemia.

\section{Acknowledgements}

This work was supported by the National Research Programme "Biomedicine 2014".

\section{Conflict of interest}

The authors declare that they have no conflict of interest. 


$\begin{array}{ll}\text { Abbreviations } & \\ \text { 1,4-DHP } & \text { 1,4-dihydropyridine } \\ \text { c-PARP1 } & \text { cleaved poly [ADP-ribose] polymerase 1 } \\ \text { D } & \text { DNA damage } \\ \text { DM } & \text { diabetes mellitus } \\ \text { DMPO } & \text { 5,5-dimethylpyrroline- } N \text {-oxide } \\ \text { DMSO } & \text { dimethyl sulfoxide } \\ \text { EDTA } & \text { ethylenediaminetetraacetic acid } \\ \text { eNOS } & \text { endothelial nitric oxide synthase } \\ \text { EPR } & \text { electron paramagnetic resonance } \\ \text { ESR } & \text { electron spin resonance } \\ \text { G } & \text { gauss } \\ \text { H2afx } & \text { H2A histone family member X, gene } \\ \text { H2AX } & \text { H2A histone family member X, protein } \\ \text { iNOS } & \text { inducible nitric oxide synthase } \\ \text { mRNA } & \text { messenger RNA } \\ \text { NaCl } & \text { sodium chloride } \\ \text { NaOH } & \text { sodium hydroxide } \\ \text { NO } & \text { nitric oxide } \\ \text { PARP1 } & \text { poly [ADP-ribose] polymerase 1 } \\ \text { PBS } & \text { phosphate-buffered saline } \\ \text { PCR } & \text { polymerase chain reaction } \\ \text { PI3K } & \text { phosphoinositide 3-kinase } \\ \text { p.o. } & \text { per os } \\ \text { SEM } & \text { standard error of the mean } \\ \text { STZ } & \text { streptozotocin } \\ \text { T1DM } & \text { type one diabetes mellitus } \\ \text { UK } & \text { United Kingdom } \\ \text { USA } & \text { United States of America } \\ \text { UV/VIS } & \text { ultraviolet-visible } \\ \text { XDH } & \text { xanthine deoxygenase } \\ & \end{array}$

\section{REFERENCES}

1. Chen X, Tang J, Xie W, Wang J, Jin J, Ren J, Jin L, Lu J. Protective effect of the polysaccharide from Ophiopogon japonicus on streptozotocin-induced diabetic rats. Carbohydr Polym 2013;94:378-85. doi: 10.1016/j.carbpol.2013.01.037

2. Fu H, Li G, Liu C, Li J, Wang X, Cheng Liu T. Probucol prevents atrial remodeling by inhibiting oxidative stress and TNF- $\alpha / \mathrm{NF}-\kappa \mathrm{B} / \mathrm{TGF}-\beta$ signal transduction pathway in alloxan-induced diabetic rabbits. J Cardiovasc Electrophysiol 2015;26:211-22. doi: 10.1111/jce. 12540

3. Drígelová M, Tarabová B, Duburs G, Lacinová L. The dihydropyridine analogue cerebrocrast blocks both T-type and L-type calcium currents. Can J Physiol Pharmacol 2009;87:923-32. doi: 10.1139/y09-086

4. Velena A, Zarkovic N, Gall Troselj K, Bisenieks E, Krauze A, Poikans J, Duburus G. 1,4-Dihydropyridine derivatives: dihydronicotinamide analogues-model compounds targeting oxidative stress. Oxid Med Cell Longev 2016;2016:1892412. doi: $10.1155 / 2016 / 1892412$

5. Fernandes MA, Pereira SP, Jurado AS, Custódio JB, Santos MS, Moreno AJ, Duburs G, Vicente JA. Comparative effects of three 1,4-dihydropyridine derivatives [OSI-1210, OSI1211 (etaftoron), and OSI-3802] on rat liver mitochondrial bioenergetics and on the physical properties of membrane lipid bilayers: relevance to the length of the alkoxyl chain in positions 3 and 5 of the DHP ring. Chem Biol Interact 2008;173:195-204. doi: 10.1016/j.cbi.2008.03.001

6. Briede J, Stivrina M, Stoldere D, Vigante B, Duburs G. Effect of cerebrocrast on body and organ weights, food and water intake, and urine output of normal rats. Cell Biochem Funct 2008;26:908-15. doi: 10.1002/cbf.1525

7. Briede J, Stivriņa M, Stoldere D, Bisenieks E, Uldriķis J, Poikāns J, Makarova N, Duburs G. Effect of new and known 1,4-dihydropyridine derivatives on blood glucose levels in normal and streptozotocin-induced diabetic rats. Cell Biochem Funct 2004;22:219-24. doi: 10.1002/cbf.1091

8. Briede J, Stivrina M, Stoldere D, Vigante B, Duburs G. Effect of cerebrocrast, a new long-acting compound on blood glucose and insulin levels in rats when administered before and after STZ-induced diabetes mellitus. Cell Biochem Funct 2007;25:673-80. doi: 10.1002/cbf.1372

9. Briede J, Stivrina M, Vigante B, Stoldere D, Duburs G. Acute effect of antidiabetic 1,4-dihydropyridine compound cerebrocrast on cardiac function and glucose metabolism in the isolated, perfused normal rat heart. Cell Biochem Funct 2008;26:238-45. doi: 10.1002/cbf.1442

10. Leonova E, Sokolovska J, Boucher JL, Isajevs S, Rostoka E, Baumane L, Sjakste T, Sjakste N. New 1,4-dihydropyridines down-regulate nitric oxide in animals with streptozotocininduced diabetes mellitus and protect deoxyribonucleic against peroxynitrite action. Basic Clin Pharmacol Toxicol 2016;119:19-31. doi: 10.1111/bcpt.12542

11. Ryabokon NI, Goncharova RI, Duburs G, RzeszowskaWolny J. A 1,4-dihydropyridine derivative reduces DNA damage and stimulates DNA repair in human cells in vitro. Mutat Res 2005;587:52-8. doi: 10.1016/j. mrgentox.2005.07.009

12. Buraka E, Chen CY, Gavare M, Grube M, Makarenkova G, Nikolajeva V, Bisenieks I, Brūvere I, Bisenieks E, Duburs G, Sjakste N. DNA-binding studies of AV-153, an antimutagenic and DNA repair-stimulating derivative of 1,4-dihydropiridine. Chem Biol Interact 2014;220:200-7. doi: 10.1016/j.cbi.2014.06.027

13. Ošina K, Rostoka E, Isajevs S, Sokolovska J, Sjakste T, Sjakste N. Effects of an antimutagenic 1,4-dihydropyridine AV-153 on expression of nitric oxide synthases and DNA repair-related enzymes and genes in kidneys of rats with a streptozotocin model of diabetes mellitus. Basic Clin Pharmacol Toxicol 2016;119:458-63. doi: 10.1111/ bcpt. 12617

14. Ošiņa K, Rostoka E, Sokolovska J, Paramonova N, Bisenieks E, Duburs G, Sjakste N, Sjakste T. 1,4-Dihydropyridine derivatives without $\mathrm{Ca} 2+$-antagonist activity up-regulate Psma6 mRNA expression in kidneys of intact and diabetic rats. Cell Biochem Funct 2016;34:3-6. doi: 10.1002/cbf.3160

15. Chen W, Feng L, Huang Z, Su H. Hispidin produced from Phellinus linteus protects against peroxynitrite-mediated DNA damage and hydroxyl radical generation. Chem Biol Interact 2012;199:137-42. doi: 10.1016/j.cbi.2012.07.001

16. Tice RR, Agurell E, Anderson D, Burlinson B, Hartmann A, Kobayashi H, et al. Single cell gel/comet assay: guidelines for in vitro and in vivo genetic toxicology testing. Environ Mol Mutagen 2000;35:206-21. doi: 10.1002/(SICI)10982280(2000)35:3<206::AID-EM8>3.0.CO;2-J 
17. Olive PL, Banáth JP. The comet assay: a method to measure DNA damage in individual cells. Nat Protoc 2006;1:23-9. doi: 10.1038/nprot.2006.5

18. Na N, Zhao DQ, Li H, Jiang N, Wen JY, Liu HY. DNA binding, photonuclease activity and human serum albumin interaction of a water-soluble freebase carboxyl corrole. Molecules. 2015;21(1):pii:E54. DOI: 10.3390/ molecules 21010054 .

19. Tsai YC, Wang YH, Liou CC, Lin YC, Huang H, Liu YC. Induction of oxidative DNA damage by flavonoids of propolis: its mechanism and implication about antioxidant capacity. Chem Res Toxicol 2012;25:191-6. doi: 10.1021/ tx200418k

20. Takahashi T, Harris RC. Role of endothelial nitric oxide synthase in diabetic nephropathy: lessons from diabetic eNOS knockout mice. J Diabetes Res 2014;2014:590541. doi: $10.1155 / 2014 / 590541$

21. Roe ND, Ren J. Nitric oxide synthase uncoupling: a therapeutic target in cardiovascular diseases. Vascul Pharmacol 2012;57:168-72. doi: 10.1016/j.vph.2012.02.004

22. Liu B, Kuang L, Liu J. Bariatric surgery relieves type 2 diabetes and modulates inflammatory factors and coronary endothelium eNOS/iNOS expression in $\mathrm{db} / \mathrm{db}$ mice. Can $\mathrm{J}$ Physiol Pharmacol 2014;92:70-7. doi: 10.1139/cjpp-20130034

23. Förstermann U, Li H. Therapeutic effect of enhancing endothelial nitric oxide synthase (eNOS) expression and preventing eNOS uncoupling. Br J Pharmacol 2011;164:21323. doi: $10.1111 / j .1476-5381.2010 .01196 . x$

24. Perdomo L, Beneit N, Otero YF, Escribano Ó, DíazCastroverde S, Gómez-Hernández A, Benito M. Protective role of oleic acid against cardiovascular insulin resistance and in the early and late cellular atherosclerotic process. Cardiovasc Diabetol 2015;14:75. doi: 10.1186/s12933-0150237-9

25. Mattila JT, Thomas AC. Nitric oxide synthase: non-canonical expression patterns. Front Immunol 2014;5:478. doi: 10.3389/fimmu.2014.00478

26. Zhang L, Dong L, Liu X, Jiang Y, Zhang L, Zhang X, Li X, Zhang Y. $\alpha$-Melanocyte-stimulating hormone protects retinal vascular endothelial cells from oxidative stress and apoptosis in a rat model of diabetes. PLoS One 2014;9:e93433. doi: 10.1371/journal.pone.0093433

27. Chen YL, Chen KH, Yin TC, Huang TH, Yuen CM, Chung SY, Sung PH, Tong MS, Chen CH, Chang HW, Lin KC, Ko SF, Yip HK. Extracorporeal shock wave therapy effectively prevented diabetic neuropathy. Am J Transl Res 2015;7:254360. PMCID: PMC4731656

28. Huang CC, Lai CJ, Tsai MH, Wu YC, Chen KT, Jou MJ, Fu PI, Wu CH, Wei IH, Effects of melatonin on the nitric oxide system and protein nitration in the hypobaric hypoxic rat hippocampus. BMC Neurosci 2015;16:61. doi: 10.1186/ s12868-015-0199-6

29. Lu QB, Feng XM, Tong N, Sun HJ, Ding L, Wang YJ, Wang $X, Z$ hou YB. Neuronal and endothelial nitric oxide synthases in the paraventricular nucleus modulate sympathetic overdrive in insulin-resistant rats. PLoS One 2015;10(10):e0140762. doi: 10.1371/journal.pone.0140762

30. Heltianu C, Guja C. Role of nitric oxide synthase family in diabetic neuropathy. J Diabetes Metab 2011;S5:002. doi: 10.4172/2155-6156.S5-002

31. Puthanveetil P, Zhang D, Wang Y, Wang F, Wan A, Abrahani A, Rodrigues B. Diabetes triggers a PARP1 mediated death pathway in the heart through participation of FoxO1. J Mol Cell Cardiol 2012;53:677-86. doi: 10.1016/j. yjmcc.2012.08.013

32. Martínez AC, Hernández M, Novella S, Martínez MP, Pagán RM, Hermenegildo C, García-Sacristán A, Prieto D, Benedito S. Diminished neurogenic femoral artery vasoconstrictor response in a Zucker obese rat model: differential regulation of NOS and COX derivatives. PLoS One 2014;9(9):e106372. doi: 10.1371/journal.pone. 0106372

33. Ahad A, Mujeeb M, Ahsan H, Siddiqui WA. Prophylactic effect of baicalein against renal dysfunction in type 2 diabetic rats. Biochimie 2014;106:101-10. doi: 10.1016/j. biochi.2014.08.006

34. Pautz A, Art J, Hahn S, Nowag S, Voss C, Kleinert H. Regulation of the expression of inducible nitric oxide synthase. Nitric Oxide 2010;23:75-93. doi: 10.1016/j. niox.2010.04.007

35. Casper I, Nowag S, Koch K, Hubrich T, Bollmann F, Henke J, Schmitz K, Kleinert H, Pautz A. Post-transcriptional regulation of the human inducible nitric oxide synthase (iNOS) expression by the cytosolic poly(A)-binding protein (PABP). Nitric Oxide 2013;33:6-17. doi: 10.1016/j. niox.2013.05.002

36. Perrotta I, Brunelli E, Sciangula A, Conforti F, Perrotta E, Tripepi S, Donato G, Cassese M. iNOS induction and PARP1 activation in human atherosclerotic lesions: an immunohistochemical and ultrastructural approach. Cardiovasc Pathol 2011;20:195-203. doi: 10.1016/j. carpath.2010.06.002

37. Chen B, Lu Y, Chen Y, Cheng J. The role of Nrf2 in oxidative stress-induced endothelial injuries. J Endocrinol 2015;225:R83-99. doi: 10.1530/JOE-14-0662

38. Kuo LJ, Yang LX. Gamma-H2AX - a novel biomarker for DNA double-strand breaks. In Vivo 2008;22:305-9. PMID: 18610740

39. Tchurikov NA, Yudkin DV, Gorbacheva MA, Kulemzina AI, Grischenko IV, Fedoseeva DM, Sosin DV, Kravatsky YV, Kretova OV. Hot spots of DNA double-strand breaks in human rDNA units are produced in vivo. Sci Rep 2016;6:25866. doi: 10.1038/srep25866 


\section{Modifikacije ekspresije gena i proteina koji su uključeni u popravak DNA i metabolizam dušikova oksida karbatonidima [derivati dinatrij-2,6-dimetil-1,4-dihidropiridin-3,5-bis(karboniloksiacetata)] u kontrolnih i dijabetičkih štakora}

Rezultati ispitivanja patogeneze komplikacija šećerne bolesti (diabetes mellitus - DM) upozoravaju na to da bi tvari koje smanjuju nastanak slobodnih radikala a pospješuju popravak DNA mogle biti obećavajuće u budućem liječenju te bolesti. U ovome su istraživanju ispitana navedena svojstva karbatonida, derivata dinatrij-2,6-dimetil-1,4-dihidropiridin-3,5bis(karboniloksiacetata). EPR spektroskopija je pokazala da je metkarbaton učinkovit sakupljač hidroksilnih radikala koji nastaju Fentonovom reakcijom. Etkarbaton i propkarbaton su bili malo manje učinkoviti, a stirilkarbaton nije bio učinkovit. UV/VIS spektroskopija pokazala je hiperkromni učinak stirilkarbatona u interakciji s DNA, a svi ostali karbatonidi pokazali su hipokromni učinak. Stakori kod kojih je DM tipa 1 induciran streptozotocinom tretirani su metkarbatonom, etkarbatonom ili stirilkarbatonom (sve tvari su davane u dozi $0,05 \mathrm{mg} \mathrm{kg}^{-1}$ ili $0,5 \mathrm{mg} \mathrm{kg}^{-1}$ ) tijekom devet dana nakon što je potvrđeno da je izazvan DM. Razine ekspresije gena u bubrezima procijenjene su kvantitativnim RT-PCR-om, ekspresija proteina - imunohistokemijski u bubrezima, srcu, ishijadičnom živcu i očima, a lom DNA - komet-testom bijelim krvnim stanicama. Indukcija DM-a uzrokovala je lomove u DNA; metkarbaton i stirilkarbaton (niska doza) ublažili su ovaj učinak. Metkarbaton i etkarbaton pojačali su mRNA i ekspresiju proteina eNOS-a u bubrezima dijabetičkih životinja; etkarbaton je takav učinak pokazao i u miokardu. Etkarbaton je smanjio ekspresiju iNOS proteina u miokardu, živcu i bubrezima. Ekspresija iNOS-a bila je pojačana u bubrezima primjenom etkarbatona i metkarbatona u dijabetičkih životinja. Razvoj DM povećao je ekspresiju iNOS-a u krvi, a etkarbaton i metkarbaton vratili su ju na normalne vrijednosti. Etkarbaton je pojačao ekspresiju H2AX u bubrezima dijabetičkih životinja, ali je smanjio proizvodnju c-PARP1. Naši podaci upućuju na potencijal karbatonida kao lijekova za liječenje komplikacija uzrokovanih dijabetesom.

KLJUČNE RIJEČI: derivati 1,4-dihidropiridina; diabetes mellitus; DNA lom; sakupljači slobodnih radikala; sintaza dušikova oksida 